\title{
Comparison of simple techniques for estimating chlorophyll a concentration in the intertidal zone using high spectral-resolution field-spectrometer data
}

\author{
Véronique Carrère ${ }^{1,3, *}$, Nicolas Spilmont $^{1}$, Dominique Davoult ${ }^{2}$ \\ ${ }^{1}$ Laboratoire Biogéochimie et Environnement du Littoral (LABEL), UMR CNRS 8013 ELICO, Université du Littoral Côte \\ d'Opale, Maison de la Recherche en Environnement Naturel, 32 avenue Foch, 62930 Wimereux, France \\ ${ }^{2}$ Station Biologique de Roscoff, UMR CNRS 7127, Université Pierre et Marie Curie, Place Georges Teissier, BP 74, \\ 29682 Roscoff Cedex, France
}

${ }^{3}$ Present address: Laboratoire de Planétologie et Géodynamique, UMR CNRS 6112, Université de Nantes, Faculté des Sciences et Techniques, 2 rue de la Houssinière, BP 92208, Nantes Cedex 3, France

\begin{abstract}
We compared 3 simple techniques for estimating the concentration of microphytobenthos chlorophyll $a$ at the sediment surface using high spectral-resolution field spectra. The techniques are based on relationships established between chlorophyll a (chl a) absorption at $673 \mathrm{~nm}$ estimated from field reflectance spectra and chl a concentration in field samples. For ease of application, the best approach should provide an estimate that is independent of the physical properties of the sediment such as grain size, moisture content, etc. and of sediment type and illumination conditions. To achieve as comprehensive a picture as possible, tidal flats from the French shore of the eastern English Channel that differed in sediment type and dynamics were studied at low tide and at various times of the year in order to cover seasonal blooms and illumination variations. The preliminary results show that all 3 methods are fairly robust $\left(R^{2}>0.8\right)$, with very little difference between them, indicating little influence of the measurement conditions on reflectance in the wavelength range used (570 to $720 \mathrm{~nm}$ ) and great stability of the instrument (a portable field spectrometer) used in the field. Validation of the 3 approaches was made with further, more recently acquired data set, and a very close correlation $\left(\mathrm{R}^{2}>0.93\right.$, slope $\left.\sim 1\right)$ was found between measured and estimated chl a concentrations for all 3 techniques at the range of chlorophyll concentrations encountered that time at the Baie de Somme site (50 to $200 \mathrm{mg} \mathrm{m}^{-2}$ ). The influence of sampling strategy and sediment optical properties with respect to spectral signatures must, however, be investigated in more detail. More measurements are required to fully validate the relationships found and to ensure that they are generally applicable to most intertidal flat environments.
\end{abstract}

KEY WORDS: Chlorophyll $a \cdot$ Reflectance spectra $\cdot$ Microphytobenthos $\cdot$ Intertidal $\cdot$ English Channel Resale or republication not permitted without written consent of the publisher

\section{INTRODUCTION}

Data on the surface concentration of microphytobenthos chl $a$ on spatial scales ranging from meters to kilometers can provide valuable information on the biomass (de Jonge 1980, Cariou-Le Gal \& Blanchard 1995 and references therein, Blanchard et al. 1996, 1997, McIntyre et al. 1996) and primary productivity (Pinckney \& Zingmark 1991, 1993, Blanchard 1994, Blan- chard \& Cariou-Le Gall 1994) in intertidal mudflats. The high primary productivity of benthic microalgae (Admiraal 1984, Colijn \& de Jonge 1984, Pinckney \& Zingmark 1993, McIntyre et al. 1996, Miller et al. 1996, Guarini et al. 2000) represents a major energy source for higher trophic levels. Therefore, a precise evaluation is required in order to obtain a sound knowledge of temporal and spatial variations in microphytobenthos dynamics. Short-term dynamics of the microphy- 
tobenthos have recently been documented by Blanchard et al. (1998) and Guarini et al. (2000) for temperate intertidal mudflats. For the intertidal area of the Bay of Marennes-Oléron (France), Guarini et al. (1998) have shown that the spatial distribution of microphytobenthic biomass is patchy, with maximum values in the center of aggregates, the size of which varies with seasons, being larger in summer during the productive period than in winter.

Some studies have also tried to establish relationships between surface concentrations of microphytobenthos chl a and critical erosion shear-stresses (Madsen et al. 1993, Underwood \& Paterson 1993, Hakvoort et al. 1998, Riethmüller et al. 1998, 2000). Data on sediment surface stability on spatial scales ranging from meters to kilometers would provide valuable information on the environmental dynamics connected with seabed morphology. It has been shown that activity of benthic microorganisms can increase the erosion threshold considerably by forming a network of extracellular polymeric substances (EPS) and by smoothing the sediment surface. Several authors (Dade et al. 1990, Madsen et al. 1993, Underwood \& Paterson 1993, Paterson et al. 1994, Amos et al. 1998) have demonstrated increased critical erosion shear-stresses with increasing EPS. Although EPS is accepted as an appropriate parameter for determining sediment stabilization, it is not appropriate for largescale mapping using optical remote-sensing. An alternative parameter is the surface concentration of the chl a of benthic microorganisms, which to some degree reflects the amount of EPS present, although the scatter of the data is large (Underwood \& Smith 1998). Several authors have reported a significant increase in critical erosion shear-stress with increasing concentration of surface chl a on intertidal flats (see Paterson et al. 1994, Riethmüller et al. 1998, Austen et al. 1999).

At present, mapping sediments or biomass in intertidal areas by conventional methods involves extensive sampling programs that are often difficult to carry out and expensive in terms of time and manpower (Guarini et al. 1998, Seuront \& Spilmont 2002). No matter how extensive such programs are, the accuracy of the resultant maps is limited by the need to extrapolate from the sampling sites to the whole area, usually by linking similar sites in a series of contours. Remotesensing may offer a more efficient method of mapping sediment distribution if sediment types or features are unique in their reflection of light and infrared radiation, since a much less extensive sampling program would be required, but would allow a more accurate extrapolation to the whole. The potential of remotesensing for mapping and monitoring intertidal areas has been realized and successfully applied by workers using both aerial photography and satellite-imagery (Folving 1984, Doerffer \& Murphy 1989). Previous studies have demonstrated that airborne and satellite sensors can provide ecologically useful information on coastal habitats, for example on intertidal vegetation (Bartlett \& Klemas 1982, Hardisky et al. 1983, Gross et al. 1988, Klemas et al. 1992, Donoghue et al. 1994), suspended sediments (Collins \& Pattiaratchi 1984, Curran et al. 1987, Bhargava \& Mariam 1992, Chen et al. 1992, Harrington et al. 1992, Bryant et al. 1996) and surface sediments (Yates et al. 1993) across extensive areas and under different tidal and phenological conditions. Many of these studies used broad-band spectral data recorded with instruments such as the Landsat Thematic Mapper (TM). Detailed mapping of intertidal seaweeds has been carried out in Canada by Zacharias et al. (1992) and in France by Bajjouk et al. (1996) using the Compact Airborne Spectrographic Imager (CASI). Remote-sensing at high spectral and spatial resolutions using instruments such as CASI enables extremely detailed land-cover mapping and has the potential to model erosion and accretion rates of intertidal surfaces. Developments in hyperspectral remotesensing have opened up the possibility of quantifying individual photosynthetic pigments within vegetation. Blackburn (1998) evaluated a range of spectral measures for estimating the pigment concentrations of individual leaves from 4 species of deciduous trees at various stages of senescence. However, most published papers present empirical relationships between pigment concentrations and various indices (e.g. Blackburn 1998); very few are based on the understanding of the physics of the reflected signal to quantitatively estimate pigment concentrations (Aber et al. 1994, Borel \& Gerstl 1994, Fourty et al. 1994, Ganapol et al. 1998, Clark et al. 2003).

The objective of this study was to compare 3 simple, physically based techniques to estimate chl a surface concentration in the intertidal zone using reflectance data from high spectral-resolution field-spectrometer reflectance. Field spectroscopy is a non-destructive technique that can be used to identify the main surface constituents based on the wavelength position of diagnostic absorptions. Concentrations can be estimated from the strength of these absorptions. It has already been operationally applied in various environmental fields (mainly environmental geology and terrestrial biology), but has only been recently applied to the study of microphytobenthic biofilms in the intertidal zone (Bryant et al. 1996, Hakvoort et al. 1998, Paterson et al. 1998, Thomson et al. 1998). The optimal approach must be easy to use and independent of conditions that could influence the surface spectral signature (e.g. sediment grain size or water content, illumination, etc.) to enable its universal application. 


\section{MATERIALS AND METHODS}

Study sites. Our study sites were located along the French coast of the eastern English Channel (Fig. 1). To include a wide range of species and a wide range of abundance, several field trips were made at various times of the year. Measurements were at low tide at 4 different test sites reflecting different environmental conditions. From north to south these were:

Site 1, Wimereux: This site is a hydrodynamically exposed sandy beach habitat typical for this shore. Measurements were performed in the upper intertidal zone, in a fairly flat area without sharp topographical features such as ripple marks, high pinnacles or deep surge channels. The substrate was homogeneous medium-grained sand (modal size $=200$ to $250 \mu \mathrm{m}$ ) . Because of the highly dynamic environment at this site, the microphytobenthos is resuspended and surface concentrations at low tide are low.

Site 2, Baie d'Authie: We measured several sites in this macrotidal estuary, where sandy to mixed sand/mud flats prevail. The substrate composition was generally fine- to medium-grained sand (modal size $=$ 200 to $350 \mu \mathrm{m}$ ), with some coarse and some very finegrained sand/mud sites. The surface concentration of microphytobenthos chl a varied as a function of sediment grain-size, estuary dynamics and season.

Site 3, Baie de Somme: The Bay of Somme is the second most important estuarine system, after the Seine estuary, and the largest sand/mud $\left(72 \mathrm{~km}^{2}\right)$ intertidal area on the French coast of the eastern English Channel. This site is similar to that in the Bay of Authie (Site 2) but as the estuary is larger here, spatial variation of the sediment occurs on a larger scale, so that our measurements represented fewer sediment types. Substrate grain-size generally varied between 125 and $250 \mu \mathrm{m}$ in the area where most measurements were performed.

Site 4, Baie de Seine: This site was very different from the other sites, since mudflats dominated in the areas in which measurements were performed. More than $50 \%$ of the sediment was comprised of particles of $<63 \mu \mathrm{m}$.

Spectral measurements. Reflectance spectra covering within the 350 to $2500 \mathrm{~nm}$ range were acquired for each station with a portable field spectrometer (ASD FieldSpec FR). The instrument has a spectral sampling interval of $1.4 \mathrm{~nm}$ in the visible near infrared (VNIR) and $2.0 \mathrm{~nm}$ in the short-wave infrared (SWIR), and a full width at half maximum (FWHM) of $3 \mathrm{~nm}$ at $700 \mathrm{~nm}$, and $10 \mathrm{~nm}$ at 1400 and $2100 \mathrm{~nm}$. We selected 2 optics ( 8 and $18^{\circ}$, depending on surface characteristics), covering a field of view of $\sim 154$ and $784 \mathrm{~cm}^{2}$ respectively, at $1 \mathrm{~m}$ height. Surface reflectance was determined by first measuring the light reflected from a calibrated white

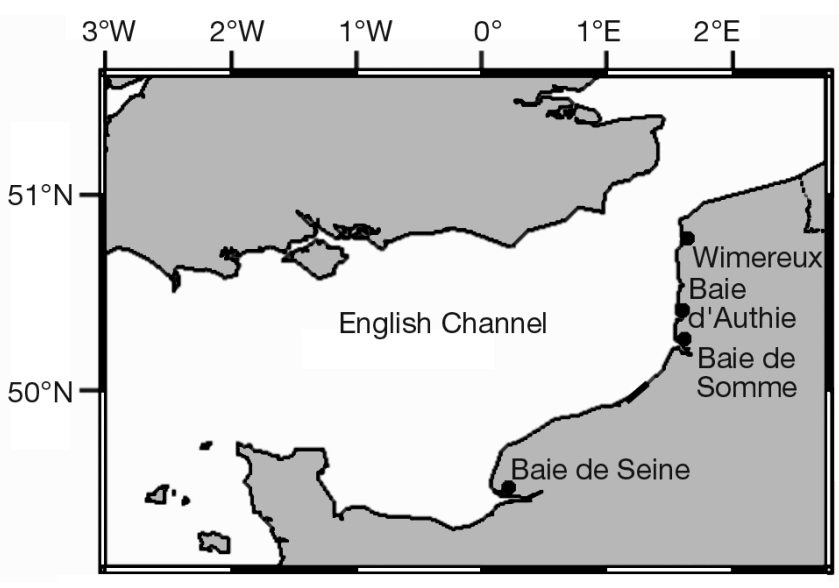

Fig. 1. Study sites along the French coast of the eastern English Channel

reference panel (Spectralon) and then light reflected by the sediment surface. Software on the portable computer linked to the spectrometer performs instantaneous conversion into reflectance after subtraction of the instrument's dark current (i.e. instrument background). Real-time display of the surface reflectance spectrum on the computer screen allows easier selection of the measurements. Several stations (between 10 and 22) were measured at each study site, covering a wide range of concentrations and sediment types. We obtained 10 spectra for each station, and calculated mean reflectance and standard deviation for each set. Fewer measurements were acquired for Wimereux (Site 1) where, as indicated by real-time spectral visualization, there was usually little microphytobenthos.

The resultant mean reflectance represented the spectral signature of the station (see Fig. 2 for examples). The spectral signature of a surface gives information about the surface composition (mineral composition of the sediment, pigments related to microphytobenthos species, moisture content, etc.) with the presence of diagnostic absorption features, unique to particular materials in shape (variation in intensity with wavelength over a narrow interval). It also provides information about the physical properties of the surface (e.g. grain-size): a gradual increase in reflectance with increasing wavelength (slope) contains information on the amount of the proportion of particles <63 $\mu \mathrm{m}$ (Hakvoort et al. 1998). Spectra of sandy areas have a steeper slope than those of muddy sediments because sandy sediment have a higher reflectance in the near infrared region (coarser grains).

Sediment sampling and analysis. Sampling and spectra measurements were made in spring 2001 and 2002 and in summer 2001. At Wimereux (Site 1) measurements were made on April 19, 2001 (clear sky); at Baie 


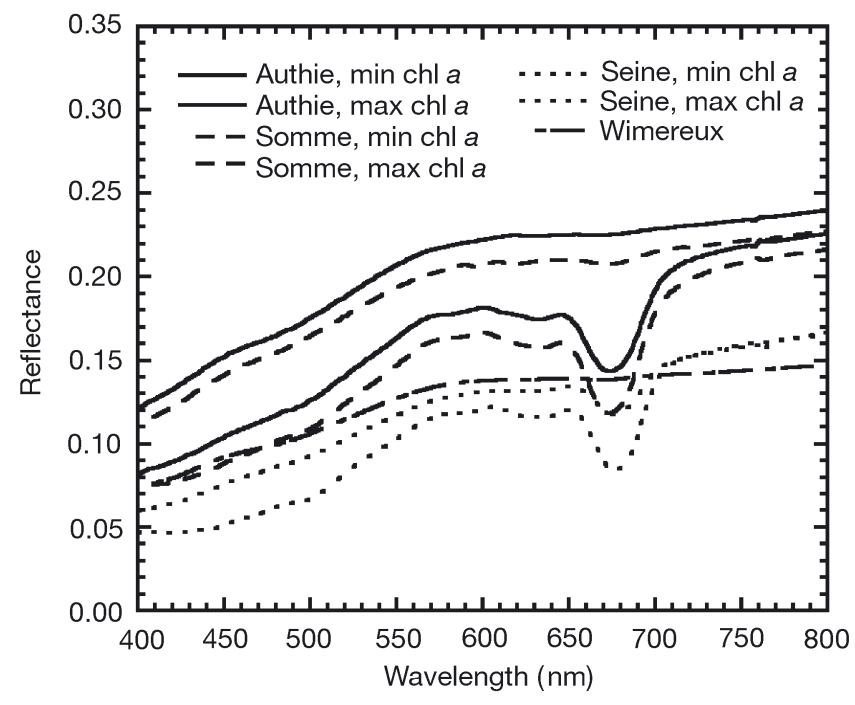

Fig. 2. Examples of surface reflectance spectra at the different sites, showing spectrum of minimum (little or no absorption) and of maximum (strong absorption, $\sim 673 \mathrm{~nm}$ ) chl a concentration for all sites (Fig. 1)

d'Authie (Site 2) on July 15, 2001 (clear sky); at Baie de Somme (Site 3) on April 17 (overcast) and June 14, 2001 (clear sky) and finally at Baie de Seine (Site 4) on March 28, 2002 (clear sky). An additional data set (May 30, 2002, Baie de Somme), under clear sky conditions, was used for algorithm validation. All measurements were made on days when low tide was close to solar noon in order to minimize directional effects on reflectance and to optimize surface exposure conditions.

For each station, sediment samples were randomly collected in the instrument field of view (FOV) using a $1.55 \mathrm{~cm}$ diameter syringe or a $3.6 \mathrm{~cm}$ diameter corer: 4 and 6 samples per measurement site for the 8 and $18^{\circ}$ optics respectively using syringes; 3 samples per site for corers and the $18^{\circ} \mathrm{FOV}$. The cores were pushed into the sediment to a depth of $1 \mathrm{~cm}$ (where most cells are concentrated: Cadée \& Hegeman 1974, Baillie 1987, Admiraal et al. 1988, Delgado 1989, de Jonge \& Colijn 1994), carefully removed, and stored in a cool box, returned to the laboratory, and stored in the dark at $-20^{\circ} \mathrm{C}$. In the laboratory, sediment sections were placed in acetone and pigments were extracted for $4 \mathrm{~h}$ in the dark at $4^{\circ} \mathrm{C}$ (Brunet 1994). After extraction, the samples were centrifuged at $4000 \mathrm{rpm}$ for $15 \mathrm{~min}$. Chl a concentrations (mg) in the supernatant were determined by spectrophotometry following the method of Lorenzen (1967):

$$
\begin{aligned}
\operatorname{chl} a= & \mathrm{V}\left[\left(11.64\left(\mathrm{OD}_{663}-\mathrm{OD}_{750}\right)-\right.\right. \\
& \left.2.16\left(\mathrm{OD}_{645}-\mathrm{OD}_{750}\right)+0.1\left(\mathrm{OD}_{630}-\mathrm{OD}_{750}\right)\right]
\end{aligned}
$$

where $\mathrm{V}=$ extraction volume and $\mathrm{OD}_{\lambda}=$ optical density at Wavelength $\lambda(\mathrm{nm})$.
As most organisms concentrate in the photic zone (i.e. in the first millimeters of sediment, with depth depending on sediment grain size: Underwood \& Paterson 1993, MacIntyre \& Cullen 1995), chl a concentrations in the supernatant were converted to units of chl a per unit surface area ( $\mathrm{chl} a_{1} \mathrm{mg} \mathrm{m}^{-2}$ ) of the sampling units. Use of this unit is justified by the fact that with typical light penetration depth of 300 to $500 \mu \mathrm{m}$ (Kühl \& Jørgensen 1994), this layer exclusively contributes to the reflectance signal of the sediment surface as measured by optical remote-sensing techniques.

Reflectance spectra analysis. Chl a absorption in the field-reflectance spectra is around $673 \mathrm{~nm}$ compared to the wavelength of $665 \mathrm{~nm}$ for pure pigment (Jeffrey \& Humphrey 1975, Jeffrey et al. 1997). However, the latter wavelength is for pure pigment in a solvent and not in a leaving cell. Tests in the laboratory with monospecific cultures also displayed absorption around 673 nm (V. Carrère et al. unpubl. data). Amount of absorption is directly related to pigment concentration and we estimated it using 3 different and simple approaches (Fig. 3).

Single band ratio (Fig. 3a): This approach has been classically used in spectroscopy and remote-sensing, generally for measuring atmospheric or surface components. It is based on a differential absorption concept (Fowle 1912, 1913), i.e. of a ratio between the reflectance at the absorption band center $\left(R_{b}\right)$ and the reflectance at a wavelength where there is no absorption attributable to chl $a$, referred to as the continuum $\left(R_{c}\right)$. We here used a ratio of reflectance at $673 \mathrm{~nm}$ (absorption):reflectance at $720 \mathrm{~nm}$ (continuum).

Normalized ratio (or scaled-band depth) (Fig. $3 b, c)$ : Since the objective was to develop a simple method that is independent of measurement conditions, some kind of normalization was necessary in order to remove the influence of other parameters on the spectral signature and to concentrate on the chlorophyll absorption itself. For example, it is well known that sediment grain-size influences diffuse reflectance, thereby changing the general shape of the spectrum through a modification of the spectral dependency of the diffusion (Hunt \& Salisbury 1970, Leu 1977). Spectral shape is also influenced by sediment optical properties such as refraction index related to sediment composition. Sediment moisture content will also modify the spectral signature (diagnostic water absorptions, change in the level of the general reflectancee.g. higher/brighter if dry, lower/darker if wet). Removing the spectrum continuum enables the spectral feature to be isolated from other effects. This approach was proposed by Clark \& Roush (1984), who determined the depth of a spectral absorption feature and related it to frost grain-size, and by Clark (1999) and Clark et al. (2003) to identify and map rocks and 
minerals with imaging spectrometer data, based on reference spectral libraries. The scaled-band depth $\left(D_{b}\right)$ is calculated as the difference between the continuum reflectance $\left(\mathrm{R}_{\mathrm{c}}\right)$ and the reflectance at the maximum depth of the absorption band $\left(\mathrm{R}_{\mathrm{b}}\right)$, normalized by the reflectance of the continuum:

$$
D_{b}=\frac{\left(R_{c}-R_{b}\right)}{R_{c}}
$$

While this band depth method is a valuable approach, its reliance on a single band means that the accuracy of the results decreases in the presence of noise in the reflectance spectrum. Noise-induced changes in the spectrum affect the depth of the absorption feature and may give erroneous chlorophyll concentration estimates.
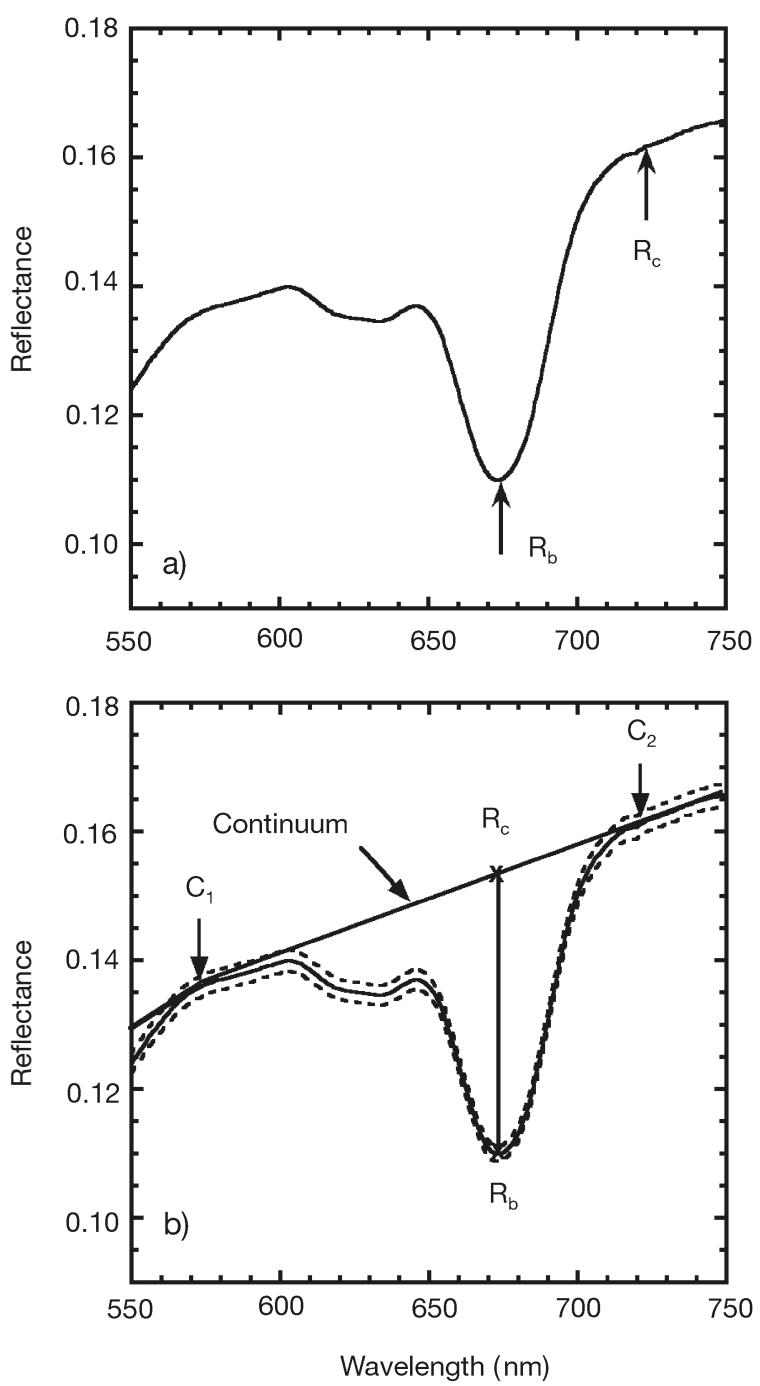

Scaled-band area (Fig. 3d): To minimize any effects of instrumental noise on retrieval of chlorophyll concentration, we estimated the strength of the absorption by calculating the scaled area of the absorption feature $\left(A_{b}\right)$ rather than simply the scaled absorption-band depth. Scaled-band area is a dimensionless quantity and is calculated by integrating the scaled absorption band-depth over the wavelengths of the absorption feature (Nolin \& Dozier 2000):

$$
\mathrm{A}_{\mathrm{b}}=\int_{\lambda} \frac{\left(\mathrm{R}_{\mathrm{c}}-\mathrm{R}_{\mathrm{b}}\right)}{\mathrm{R}_{\mathrm{c}}}
$$

While the exact distribution of sensor noise is not known, a normal distribution has been used by others in examining sensor-noise characteristics (Sabol et al.
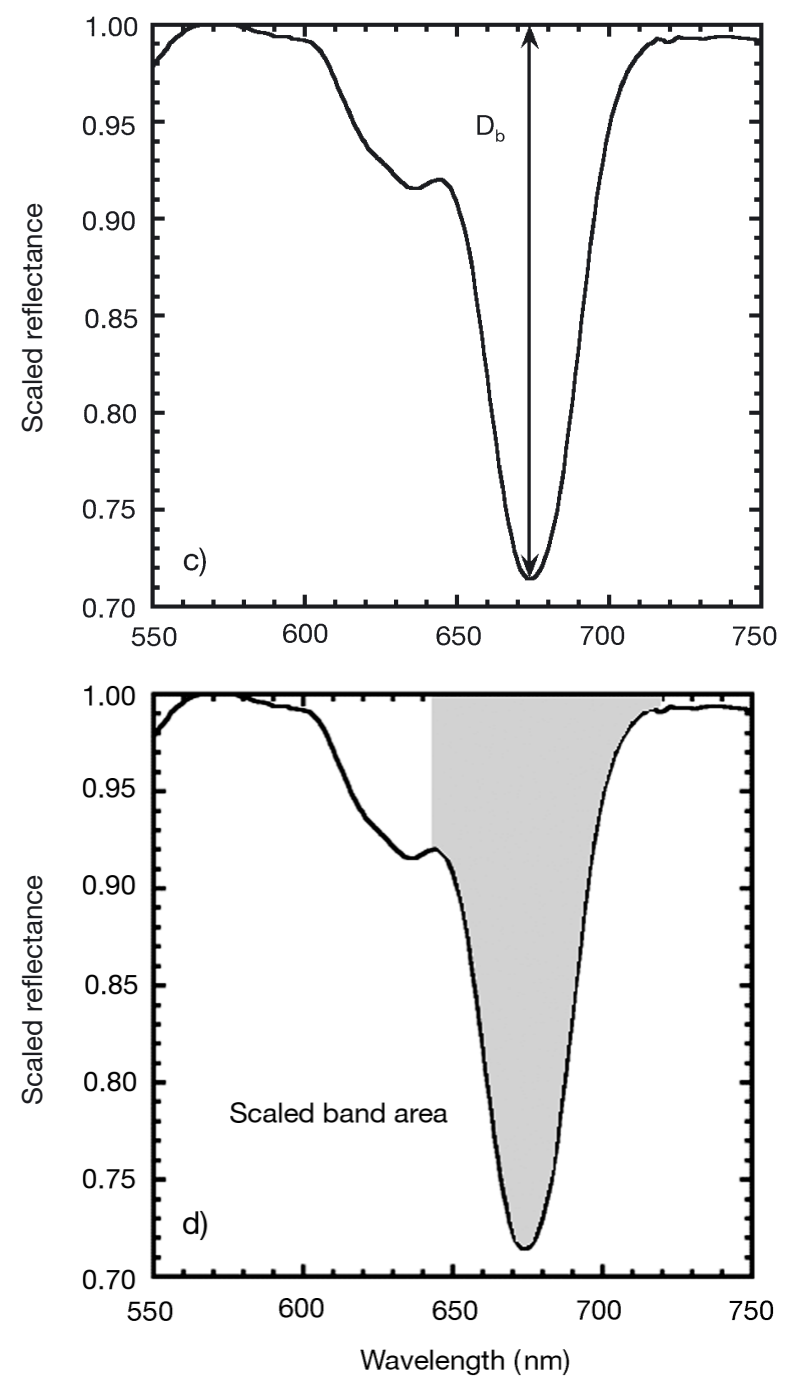

Fig. 3. Estimated chl a absorption. (a) Single-band ratio $R_{b} / R_{c i}$ (b) continuum removal. Continuum is fit between selected endpoints $C_{1}$ and $C_{2}$; band-depth $\left(D_{b}\right)$ computed using reflectance $\left(R_{b}\right)$ and corresponding continuum reflectance $\left(R_{c}\right)$ at the band center. Dashed lines represent mean surface reflectance (10 measurements) plus or minus standard deviation; (c) normalized ratio or scaled-band depth (after continuum removal); (d) scaled-band area (in gray) after continuum removal 

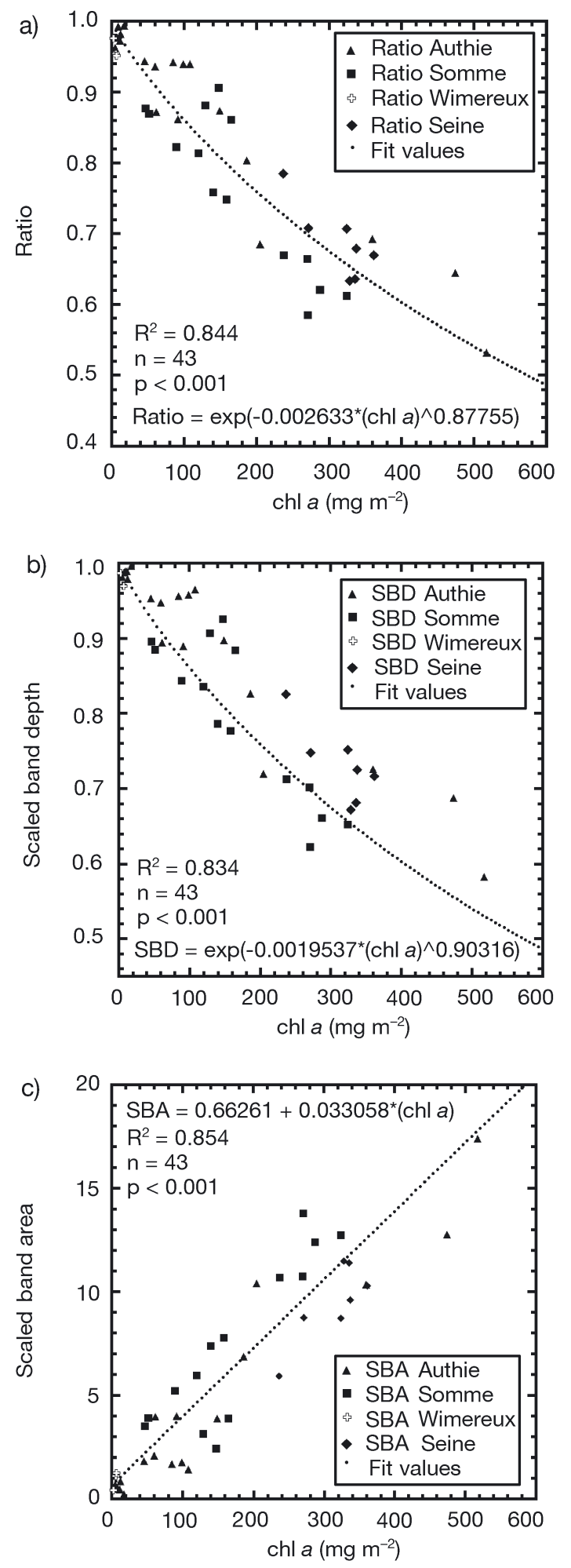

Fig. 4. Regression relationships used to estimate chl a concentration. $x$-axis is chl $a$ in the samples, $y$-axis is the estimation of the strength of the absorption from the surface reflectance: (a) single-band ratio (Ratio); (b) normalized ratio or scaledband depth (SBD); (c) scaled-band area (SBA). $\mathrm{n}=$ number of samples used in the regression
1992). Integration over the absorption feature should average out the fluctuations of the reflectance caused by noise and produce a more realistic estimate of absorption strength. Integration was restricted to the 650 to $720 \mathrm{~nm}$ wavelength range in order to avoid the influence of other absorbing pigments such as chlorophyll $C$ (absorption at 590 and $635 \mathrm{~nm}$ ).

For each method, regression relationships were calculated between absorption estimated from spectra and mean chl a concentration determined from the actual samples.

Abnormal values ( 15\% of the measurements) that could be related to sampling strategy were eliminated before calculating the mean chl a concentration and the goodness of fit in each case.

\section{RESULTS AND DISCUSSION}

As is already well known in atmospheric physics and spectroscopy, the dependency of absorption depth (simple ratio) or normalized absorption depth (normalized ratio) to chl a concentration can be approximated by an exponential function fit (Beer Lambert-like law) (Fig. 4a,b). The functional relationship between scaled-band area and chl a concentration was assumed to be a linear function (Fig. 4c); 43 samples were included in the calculations; chl a concentration ranged from 0 to $520 \mathrm{mg} \mathrm{m}^{-2}$.

Our results were rather satisfactory. All 3 approaches achieved similar results $\left(\mathrm{R}^{2}>0.8\right)$, indicating very little influence of measurement conditions on the estimation of absorption due to chl a. The scaled-band area method gave slightly better results with an $\mathrm{R}^{2}$ of 0.85 . This could reflect little variation in sediment grain-size (most samples were in the 125 to $250 \mu \mathrm{m}$ grain-size range) and therefore no major change of the general slope of the reflectance at the wavelengths used, or little variation in water content, or that our sampling was not fully representative. The typical spectra in Fig. 2 display no obvious changes in general shape other than the specific absorption features related to pigment concentrations. The Baie de Somme (Site 3) and Baie d'Authie (Site 2) spectra are very similar while the Baie de Seine (Site 4) and Wimereux (Site 1) spectra have lower average brightness or albedo. As shown by Kühl et al. (1994) and Kühl \& Jørgensen (1994), such differences can be related to variations in grain size and enhanced moisture content. Increasing moisture content results in increasingly lower reflectance towards longer wavelengths, and the higher refractive index of water compared to air causes changes in the light field. Moreover, sediment-surface reflectance also results from light attenuation in the sediment due to both absorption and multiple-scattering, whereby 
scattering enhances the probability of absorption. Therefore, scattering intensity increases with decreasing particle size, photons are scattered multiple times and, as there is a probability of absorption at each encounter with a sediment particle, the overall result is a higher attenuation of light even though the absorption properties of the sediment have not changed. We are currently analyzing in more detail the influence of sampling strategy and sediment optical properties with respect to spectral signatures.

The instrument we used proved to be stable, with very little noise (see very small standard deviation in Fig. 3b). The result would be different when these methods are applied to airborne or spaceborne data where instrument noise is much higher due to electronic interference.

We validated each technique using a further data set from Baie de Somme (May 30, 2002). Chl a concentration was estimated by inverting the 3 previously derived functions (see Fig. 4) on the reflectance spectra. This estimation was then compared to the chl a concentration in the 10 samples. Fig. 5 shows the strong correlation $\left(\mathrm{R}^{2}>0.9, \mathrm{p}<0.001\right)$ between estimated (chl a inv) and measured chl a (chl a meas) concentration, no matter which algorithm is used, for the range of chl a concentrations encountered that day (50 to $200 \mathrm{mg} \mathrm{m}^{-2}$ ). More measurements under different conditions are still necessary to further validate these results, in particular measurements in fine sediment $(<63 \mu \mathrm{m})$.

The present research allowed us to compile a statistically robust data-set of reflectance spectra for the most important sediment-surface types under different illumination conditions (clear and overcast skies) and a wide range of chl a concentrations (0 to $520 \mathrm{mg} \mathrm{m}^{-2}$ ). However, to improve the statistical significance of the above functional relations, more data are needed covering a wider range of intertidal sediment types. Apparently, the range of sediment grain size associated with various microphytobenthic chl a concentration is not broad enough to be sure that substrate particle-size does not have a major effect on spectral signature. All sites had similar spectral shapes, with almost no variation in slope. We plan sampling at other sites on the French coast, as well as in fall and winter, to investigate the influence of other illumination and biogenic conditions.

Several sources of uncertainty arising from 3 main sources must be investigated further: (1) Spatial sampling strategy versus spectral measurement. A varying number of samples of varying diameter was randomly collected in the instrument FOV. Such sampling may not represent what is actually measured by the spectrometer, even though some of the bias can be reduced by eliminating 'inconsistent' values (i.e.
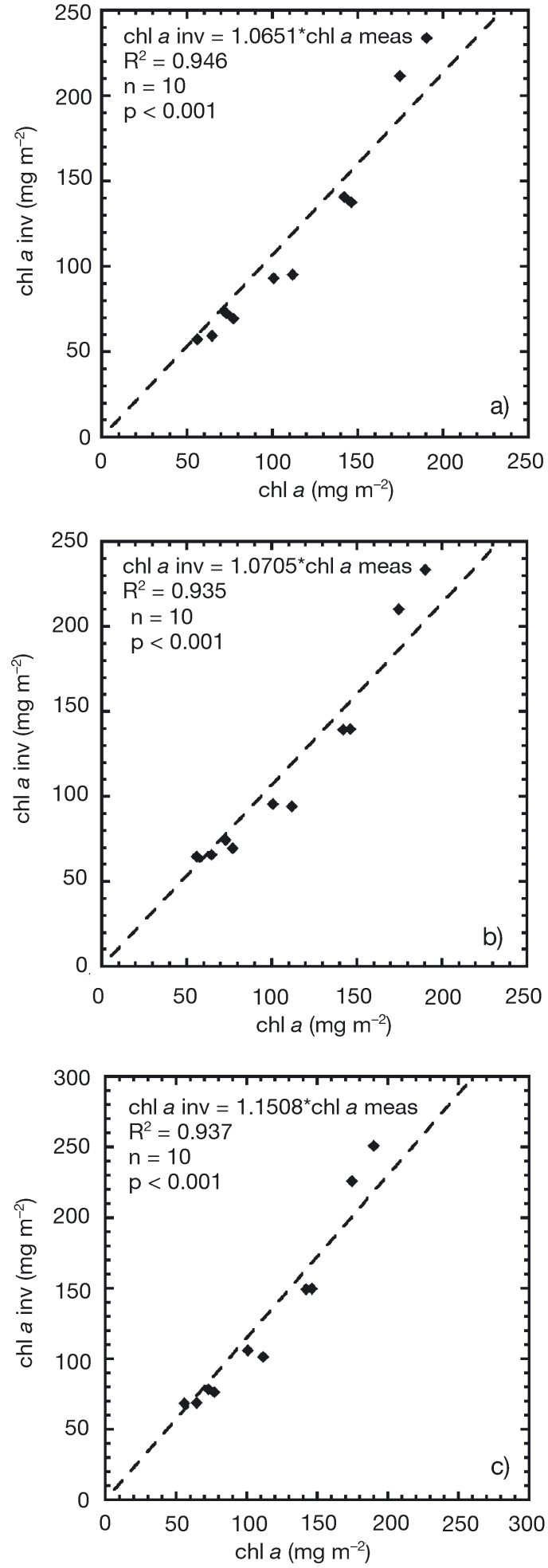

Fig. 5. Comparison between chlorophyll a measured in the samples (chl a meas) from the Baie de Somme May 2002 campaign, and chlorophyll a derived from the field spectra ( $\mathrm{chl} a$ inv), inverting the equations derived from the training data set (Fig. 4) for each method: (a) single band ratio; (b) normalized ratio or scaled-band depth; (c) scaled-band area 
spectral values that are obviously too high or too low). We are presently investigating the validity of this sampling strategy by comparing the results of 2 types of sampling (syringes and corers) at the same sites in Baie d'Authie. Additional measurements will be performed in Baie de Somme in the fall to determine possible influence of the patchiness of the microphytobenthos biofilms. (2) Chlorophyll extraction from cores up to a $1 \mathrm{~cm}$ depth. Microphytobenthic algae can be present down to several centimeters depth in the sediment (Cadée \& Hegeman 1974), and are thus included in the amount of chl a extracted from the $1 \mathrm{~cm}$ thick cores. But the layer of substrate that contributes to the reflectance at the sediment surface, measured by the field spectrometer, is less than a few millimeters thick (Ploug et al. 1993, Kühl \& Jørgensen 1994, Kühl et al. 1994). Therefore, we are probably overestimating the amount of chl a which contributes to the absorption observed in the reflectance spectra. (3) Possible vertical migration of the diatoms. It is also known that diatoms migrate vertically (Harper 1977, Paterson 1986, Hay et al. 1993, Blanchard et al. 1998). Similarly, this can affect the regression relationship between chl a present in the samples and absorption strength as measured by the field spectrometer. 'Hidden' benthic diatoms would be accounted for in the chl a concentration in the sample but would not contribute to the reflectance of the surface. The result is again an overestimation of the chl a contribution to the measured signal. This migrating behavior was not observed in the field during our experiments, since most of our data was acquired under similar tidal conditions, but it could account for some of the 'inconsistent' values.

\section{Conclusions}

Herein, we have presented preliminary results on 3 simple techniques (band-ratio, scaled-band depth and scaled-band area) for estimating chl a concentration of microphytobenthos at the sediment surface from high spectral-resolution field-reflectance spectra. These techniques are based on regression relationships calculated between chl a absorption around $673 \mathrm{~nm}$, estimated from field-reflectance spectra and surface chl a concentration derived from field samples in different ways. Our aim was to find an optimal approach that is independent of sediment physical properties (grain size, moisture content, etc.) and sediment type as well as illumination conditions. Our results show that all 3 methods are robust $\left(R^{2}>0.8\right)$, with very little difference between them, implying little effect of measurement conditions on reflectance in the wavelength range employed (570 to $720 \mathrm{~nm}$ ) and great stability of the instrument used in the field. Calculating the scaled-band area of the absorption feature did not, therefore, significantly improve the estimation.

All 3 approaches were validated with a recently acquired data set, and a very good correlation $\left(\mathrm{R}^{2}>\right.$ 0.93, slope close to 1) was found between measured and estimated chl a concentrations for all 3 techniques in the range of chlorophyll concentration at that site (50 to $200 \mathrm{mg} \mathrm{m}^{-2}$ ).

We are conducting further studies to achieve a better understanding of the effect of sampling strategy (particularly as regards estimation of chl a concentration in the first $1 \mathrm{~cm}$ of sediment) and the optical properties of sediment with regard to spectral signatures. More measurements are required to fully validate these relationships and ensure they can be generalized to most intertidal flat environments.

Hyperspectral images were not available during this study, but we plan future investigations to adapt the selected approach to imaging spectrometer data to produce a spatial map of the distribution of chl a that would help us achieve a better understanding of the various biological processes occurring in the intertidal zone such as production, removal or re-suspension of microphytobenthos during immersion or impact of grazing on microphytobenthos species, etc.

We are also investigating the possibility of using such approach to identify and quantify other pigments. This would enable estimations of biodiversity, since pigments are reliable fingerprints for identifying different groups of microalgae (Andersen et al. 1996, Barranguet et al. 1997).

Acknowledgements. This work was supported by the French 'Programme National d'Environnement Côtier' and the 'Seine Aval' project. We would like to thank Samuel Degézelle for helping with the chlorophyll a extraction and Aurélie Robin for analyzing the Bay of Authie sediment samples. We also thank reviewers for their constructive comments.

\section{LITERATURE CITED}

Aber JD, Bolster K, Newman SD, Soulia M, Martin ME (1994) Analysis of forest foliage. II. Measurement of the carbon fraction and nitrogen content by end-member analysis. J Near-Infrared Spectrosc 2:15-23

Admiraal W (1984) The ecology of estuarine sedimentinhabiting diatoms. Progr Phycol Res 3:269-322

Admiraal W, van Arkel MA, Baretta JW, Colijn F, Ebenhöh W, de Jonge VN, de Kop A, Ruardij P, Schröder HGJ (1988) The construction of the benthic submodel. In: Baretta J, Ruardij P (eds) Tidal flat estuaries: simulation and analysis of the Ems estuary. Ecological studies 71. Springer-Verlag, Heidelberg, p 105-152

Amos CL, Brylinsky TF, Sutherland TF, O'Brien D, Lee S, Cramp A (1998) The stability of a mudflat in the Humber estuary, South Yorkshire, UK. In: Black KS, Paterson DM, 
Cramp A (eds) Sedimentary processes in the intertidal zone. Geological Society Special Publication, No. 139. The Geological Society, London, p 25-43

Andersen RA, Bidigare RR, Keller MD, Latasa M (1996) A comparison of HPLC pigment signatures and electron microscopic observations for oligotrophic waters of the North Atlantic and Pacific Oceans. Deep-Sea Res 43: $517-537$

Austen I, Andersen TJ, Edelvang K (1999) The influence of benthic diatoms and invertebrates on the erodability of an intertidal mudflat in the Danish Wadden Sea. Estuar Coast Shelf Sci 49:99-111

Baillie PW (1987) Diatom size distribution and community stratification in estuarine intertidal sediments. Estuar Coast Shelf Sci 25:193-209

Bajjouk T, Guillaumont B, Populus J (1996) Application of airborne imaging spectrometry system data to intertidal seaweed classification and mapping. Hydrobiologia 326/327: 463-471

Barranguet C, Herman PMJ, Sinke JJ (1997) Microphytobenthos biomass and community studied by pigment biomarkers: importance and fate in the carbon cycle of a tidal flat. J Sea Res 38:59-70

Bartlett DS, Klemas V (1982) In situ spectral reflectance studies of tidal wetland grasses. Photogramm Eng Remote Sens 47:1695-1703

Bhargava DS, Mariam DW (1992) Cumulative effects of salinity and sediment concentration on reflectance measurements. Int J Remote Sens 13:2151-2159

Blackburn GA (1998) Quantifying chlorophylls and carotenoids at leaf and canopy scales: an evaluation of some hyperspectral approaches. Remote Sens Environ 66: 273-235

Blanchard GF (1994) Caractéristiques photosynthétiques du microphytobenthos d'une vasière intertidale. CRASc Paris (Life Sciences) 317:633-673

Blanchard GF, Cariou-Le Gall V (1994) Photosynthetic characteristics of microphytobenthos in Marennes-Oléron Bay, France: preliminary results. J Exp Mar Biol Ecol 182:1-14

Blanchard GF, Guarini JM, Richard P, Gros P, Mornet F (1996) Quantifying the short-term temperature effect of lightsaturated photosynthesis of intertidal microphytobenthos. Mar Ecol Prog Ser 134:309-313

Blanchard GF, Guarini JM, Gros P, Richard P (1997) Seasonal effect on the relationship between the photosynthetic capacity of intertidal microphytobenthos and temperature. J Phycol 33:723-728

Blanchard GF, Guarini JM, Bacher C, Huet V (1998) Contrôle de la dynamique à court terme du microphytobenthos intertidal par le cycle exondation-submersion. CRASc Paris (Life Sciences) 321:501-508

Borel CC, Gerstl SAW (1994) Nonlinear spectral mixing models for vegetative and soil surfaces. Remote Sens Environ 47:403-416

Brunet C (1994) Analyse des pigments photosynthétiques par HPLC: communautés phytoplanctoniques et productivité primaire en Manche orientale. PhD thesis, Univ Paris VI

Bryant RG, Tyler AN, Gilvear DJ, McDonald P, Teasdale I, Ferrier G (1996) A preliminary investigation into the VNIR spectral characteristics of inter-tidal estuarine sediments. Int J Remote Sens 17:405-412

Cadée GC, Hegeman J (1974) Primary production of the benthic microflora living on tidal flats in the Dutch Wadden Sea. Neth J Sea Res 8:260-291

Cariou-Le Gall V, Blanchard GF (1995) Monthly HPLC measurements of pigment concentration from an intertidal muddy sediment of Marennes-Oléron Bay, France. Mar
Ecol Prog Ser 121:171-179

Chen Z, Curran PJ, Hanson JD (1992) Derivative reflectance spectroscopy to estimate suspended sediment concentration. Remote Sens Environ 40:67-77

Clark RN (1999) Chapter 1: Spectroscopy of rocks and minerals and principles of spectroscopy. In: Rencz AN (ed) Manual of remote sensing. John Wiley \& Sons, New York, p 3-58

Clark RN, Roush T (1984) Reflectance spectroscopy: quantitative analysis techniques for remote sensing applications. J Geophys Res 89:6329-6340

Clark RN, Swaize GA, Livo KE, Kokaly RF, Sutley SJ, Dalton JB, McDougal RR, Gent CA (2003) Imaging spectroscopy: Earth and planetary remote sensing with the USGS Tetracorder and Expert Systems. J Geophys Res 108:(E12):5131, doi: 10.1029/2002JE001847

Colijn F, de Jonge VN (1984) Primary production of microphytobenthos in the Ems-Dollard Estuary. Mar Ecol Prog Ser 4:9-21

Collins M, Pattiaratchi C (1984) Identification of suspended sediment in coastal waters using Airborne Thematic Mapper data. Int J Remote Sens 5:635-657

Curran PJ, Hansom JD, Plummer SE, Pedley MI (1987) Multispectral remote sensing of nearshore suspended sediments: a pilot study. Int J Remote Sens 8:103-112

Dade WB, Davis JD, Nichols PD, Nowell ARM, Thistle D, Trexler MB, White DC (1990) Effects of bacterial exopolymer adhesion on the entrainment of sand. Geomicrobiol $8: 1-16$

de Jonge VN (1980) Fluctuations in the organic carbon to chlorophyll a ratio for estuarine benthic diatom populations. Mar Ecol Prog Ser 2:345-353

de Jonge VN, Colijn F (1994) Dynamics of microphytobenthos biomass in the Ems estuary. Mar Ecol Prog Ser 104: 185-196

Delgado M (1989) Abundance and distribution of microphytobenthos in the bays of Ebro Delta (Spain). Estuar Coast Shelf Sci 29:183-194

Doerffer R, Murphy D (1989) Factor analysis and classification of remotely sensed data for monitoring tidal flats. Helgol Meeresunters 43:275-293

Donoghue DNM, Thomas DCR, Zong Y (1994) Mapping and monitoring the intertidal zone of the east coast of England using remote sensing techniques and coastal monitoring GIS. Mar Technol Soc J 28:19-29

Folving S (1984) The Danish Wadden Sea: thematic mapping by means of remote sensing. Folia Geogr Dan 15:1-56

Fourty T, Baret F, Jaquemoud S, Schmuck G, Verdebout J (1994) Leaf optical properties with explicit description of its biochemical composition: direct and inverse problem. Remote Sens Environ 56:104-117

Fowle FE (1912) The spectroscopic determination of aqueous vapor. Astrophys J 35:149-153

Fowle FE (1913) The determination of aqueous water vapor above Mount Wilson. Astrophys J 37:359-372

Ganapol BD, Johnson LF, Hammer PD, Hlavka CA, Peterson DL (1998) LEAFMOD: a new within leaf radiative transfer model. Remote Sens Environ 63:182-193

Gross MF, Klemas V, Levasseur JE (1988) Remote sensing of biomass of salt marsh vegetation in France. Int $\mathrm{J}$ Remote Sens 9:397-408

Guarini JM, Blanchard G, Bacher C, Gros P and 6 others (1998) Dynamics of spatial patterns of microphytobenthic biomass: inferences from a geostatistical analysis of two comprehensive surveys in Marennes-Oléron Bay (France). Mar Ecol Prog Ser 166:131-141

Guarini JM, Blanchard GF, Gros P, Gouleau D, Bacher C 
(2000) Dynamic model of the short term variability of microphytobenthic biomass on temperate intertidal mudflats. Mar Ecol Prog Ser 195:291-303

Hakvoort JHM, Heineke M, Heymann K, Kühl H, Riethmüller R, Witte G (1998) A basis for mapping the erodability of tidal flats by optical remote sensing. Mar Freshw Res 49: $867-873$

Hardisky MA, Smart RM, Klemas V (1983) Seasonal spectral characteristics and aboveground biomass of the tidal marsh plant Spartina alterniflora. Photogramm Engin Remote Sens 49:85-92

Harper MA (1977) Movements. In: Werner D (ed) Botanical monographs, Vol 13. The biology of diatoms. Blackwell Scientific Publications, Oxford, p 224-249

Harrington JA, Schiebe FR, Nix JF (1992) Remote sensing of the Lake Chicot, Arkansas: monitoring suspended sediments, turbidity, and secchi depth with Landsat MSS data. Remote Sens Environ 39:15-27

Hay SI, Maitland TC, Paterson DM (1993) The speed of diatom migration through natural and artificial substrata. Diatom Res 8:371-384

Hunt GR, Salisbury JW (1970) Visible and near-infrared spectra of minerals and rocks. I. Silicate minerals. Mod Geol 1:283-300

Jeffrey SW, Humphrey GF (1975) New spectrophotometric equations for determining chlorophylls $a, b, c_{1}$ and $c_{2}$ in higher plants algae and natural phytoplankton. Biochem Physiol Pflanz 167:191-194

Jeffrey SW, Matoura RFC, Wright SW (eds) (1997) Phytoplankton pigments in oceanography: guidelines to modern methods. UNESCO Publishing, Paris

Klemas VV, Hardisky MA, Wolf PL, Gross MF (1992) Remote sensing of biomass and stress in coastal wetlands. First thematic conference for marine and coastal environments, New Orleans. Environmental Research Institute, Michigan, Vols 1 and 2, 102:843-844

Kühl M, Jørgensen BB (1994) The light field of microbenthic communities: radiance distribution and microscale optics of sandy coastal sediments. Limnol Oceanogr 39:1368-1398

Kühl M, Lassen C, Jørgensen BB (1994) Light penetration and light intensity in sandy marine sediments measured with irradiance and scalar irradiance fiber-optic microprobes. Mar Ecol Prog Ser 105:139-148

Leu DJ (1977) Visible and near-infrared reflectance of beach sands: a study on the spectral reflectance/grain size relationship. Remote Sens Environ 6:169-182

Lorenzen CJ (1967) Determination of chlorophyll and phaeopigments: spectrometric equations. Limnol Oceanogr 12: 343-346

Madsen KN, Nilson P, Sundbäck K (1993) The influence of benthic micro algae on the stability of a subtidal sediment. J Exp Mar Biol Ecol 170:159-177

McIntyre HL, Cullen JJ (1995) Fine-scale vertical resolution of chlorophyll and photosynthetic parameters in shallowwater benthos. Mar Ecol Prog Ser 122:227-237

McIntyre HL, Geider RJ, Miller DC (1996) Microphytobenthos: the ecological role of the 'secret garden' of unvegetated, shallow-water marine habitats: distribution, abundance and primary production. Estuaries 19:186-201

Miller DC, Geider RJ, McIntyre HL (1996) Microphytobenthos: the ecological role of the 'secret garden' of unvege-

Editorial responsibility: Otto Kinne (Editor), Oldendorf/Luhe, Germany tated, shallow-water marine habitats. II. Role in sediment stability and shallow water food webs. Estuaries 19: 202-212

Nolin AW, Dozier J (2000) A hyperspectral method for remotely sensing the grain size of snow. Remote Sens Environ 74:207-216

Paterson DM (1986) The migratory behaviour of diatom assemblages in a laboratory tidal micro-ecosystem examined by low temperature scanning electron microscopy. Diatom Res 1:227-239

Paterson DM, Yallop ML, George C (1994) Spatial variability in the sediment erodability on the Island of Texel. In: Krummbein W, Paterson DM, Stal LJ (eds) Biostabilization of sediments. Oldengurg, Munich, p 107-120

Paterson MD, Wiltshire KH, Miles A, Blackburn J, Davidson I, Yates MG, McGrorty S, Eastwood JA (1998) Microbiological mediation of spectral reflectance from intertidal cohesive sediments. Limnol Oceanogr 43:1207-1221

Pinckney JL, Zingmark RG (1991) Effects of tidal stage and sun angles on intertidal benthic microalgal productivity. Mar Ecol Prog Ser 76:81-89

Pinckney JL, Zingmark RG (1993) Modeling the annual production of intertidal benthic microalgae in estuarine ecosystems. J Phycol 29:396-407

Ploug H, Lassen C, Jørgensen BB (1993) Action spectra of microalgal photosynthesis and depth distribution of spectral scalar irradiance in a coastal marine sediment of Limfjorden, Denmark. FEMS Microbiol Ecol 102:261-270

Riethmüller R, Hakvoort JHM, Heineke M, Heymann K, Kühl H, Witte G (1998) Relating erosion shear stress to tidal flat surface color. In: Black KS, Paterson DM, Cramp A (eds) Sedimentary processes in the intertidal zone. Geological Society Special Publication, No. 139. The Geological Society, London, p 283-293

Riethmüller R, Heineke M, Kühl H, Keuker-Rüdiger R (2000) Chlorophyll a concentration as an index of sediment stabilization by microphytobenthos? Cont Shelf Res 20: $1351-1372$

Sabol DE Jr, Adams JB, Smith MO (1992) Quantitative subpixel spectral detection of targets in multispectral images. J Geophys Res 97:2659-2672

Seuront L, Spilmont N (2002) Self-organized criticality in intertidal microphytobenthos patch patterns. Physica A 313:513-539

Thomson AG, Eastwood JA, Yates MG, Fuller RM, Wadsworth RA, Cox R (1998) Airborne remote sensing of intertidal biotopes: BIOTA I. Mar Pollut Bull 37:164-172

Underwood GJC, Paterson DM (1993) Seasonal changes in diatom biomass, sediment stability and biogenic stabilization in the Severn Estuary. J Mar Biol Assoc UK 73:871-887

Underwood GJC, Smith DJ (1998) Predicting epipelic diatom exopolymer concentration in intertidal sediments from sediment chlorophyll a. Microb Ecol 35:116-125

Yates MG, Jones AR, McGrorty S, Goss-Custard JD (1993) The use of satellite imagery to determine the distribution of intertidal surface sediments of the Wash, England. Estuar Coast Shelf Sci 36:333-344

Zacharias M, Olaf N, Borstad G (1992) An assessment and classification of a multispectral bandset for the remote sensing of intertidal seaweeds. Can J Remote Sens 18: 263-274

Submitted: January 21, 2003; Accepted: October 5, 2003 Proofs received from author(s): June 8, 2004 